ISSN 1412 - 3681

\title{
Counting Teller Quantity For Better Queue In Financial Institution: Case of Bank Central Asia, Metro Indah Mall Branch Office-Bandung
}

\author{
CUT I. SETIAWATI, FARAH A. BUDYANNA \\ Business Administration, Faculty of Communication and Business, Telkom University, Bandung 40257, Indonesia \\ Email correspondence: setiawaticutirna@gmail.com, irnacut@telkomuniversity.ac.id
}

\begin{abstract}
A queue is frequently encountered in financial transaction at the bank. The similar thing also occurs at Bank Central Asia (BCA), Bandung. BCA Bank actually has SOP stating that it allocates 5 minutes for financial service at the teller. This research aims to precisely determine the total calculation of teller at BCA Bank. Research methodology uses a quantitative method and it encompasses the descriptive research where the operational variable functioned is a multichannel-single phase $(\mathrm{M} / \mathrm{M} / \mathrm{S})$. There is more than one teller operating and there is only one service phase that must be passed by the customers to finish the transaction. The results showed that each teller could serve 10 persons per hour and teller busy level is $97 \%$. The average time spent by each customer in the system is 63 minutes and in the queue line is 57 minutes. This research results showed that there should be 7 tellers to get an optimal result, meaning that BCA Bank should provide three more tellers per day. Providing more tellers will indicate better benefits for the customer.
\end{abstract}

Key words: Queue system M/M/S, Teller, Financial Service.

\section{Pengaruh Keberadaan Komite Pengawasan dan Tingkat Pengungkapan Sukarela pada Harga Saham di Indonesia}

\begin{abstract}
Abstrak
Antrian sangat sering dijumpai ketika bertransaksi di bank. Begitu juga di Bank Central Asia (BCA) Cabang Metro Indah Mall (MIM) Bandung. Sebenarnya pada bank tersebut terdapat Standar Opersional Prosedur (SOP) selama 5 menit untuk waktu menunggu nasabah ketika menerima pelayanan di teller, antrian tetap saja terjadi. Tujuan dari penelitian ini adalah untuk menentukan jumlah teller yang tepat untuk Bank BCA. Metode penelitian ini menggunakan metode penelitian kuantitatif dan merupakan jenis penelitian deskriptif dimana variable operasional yang digunakan adalah sistem antrian multichannel-single phase (M/M/S) karena terdapat lebih dari satu server/teller yang beroperasi dan hanya ada satu tahapan pelayanan yang harus dilalui oleh nasabah untuk menyelesaikan transaksi. Dari keadaan diketahui pula bahwa kemampuan teller untuk melayani nasabah adalah 10 orang setiap jamnya dengan tingkat kesibukan teller sebesar 97\%. Perhitungan waktu rata-rata seorang nasabah dalam sistem adalah selama 63 menit, waktu rata-rata yang dibutuhkan seorang nasabah untuk menunggu dalam antrian adalah 57 menit. Kemudian peneliti melakukan perhitungan terhadap jumlah teller yang tepat, dengan tujuan untuk meminimalisir antrian. Penelitian ini menghasilkan perhitungan sebanyak 7 teller. Artinya, bank yang diteliti dapat menambahkan teller sebanyak 3 orang/ hari. Dengan penambahan jumlah teller maka akan mengindikasi adanya manfaat yang lebih kepada konsumen.
\end{abstract}

Kata kunci: Sistem antrian M/M/S, Teller, Jasa Keuangan. 


\section{INTRODUCTION}

In the global competitive era, companies currently should present better service fast and easily especially related to the queue system (Sunarya, Aritonang, and Helmi, 2015). For consumers, wasting time in the queue line is a disadvantage, so there is a need to develop a working system or queue service system which is faster for attracting sympathy and improving the customer satisfaction. Banks is one of the institutions which may potentially form the existence of a sizeable queue line (Arikunto, 2006). Customers who are waiting in the queue line obstruct the productivity of each individual involved in it (Ivancevich et al., 1997). Each transaction in a financial institution such a bank would be served by tellers where all customers to be served should go through a queue line. Bank Central Asia (BCA) branch of Metro Indah Mall (MIM) Bandung has queue experiences. In daily financial activities, BCA Bank implements a multichannel-single phase queue type where the queue system uses a numbering system. The customers are required to take a queue number first before going through the transaction process. In an effort to provide effective and efficient services, BCA Bank has a 5 minutes duration as the Standard Operational Procedures (SOP) to serve customers at the teller per transaction per customer. Here is the number of customers who queue and are serviced by teller:

Table 1. Amount of serviced customer in a day per hour

\begin{tabular}{cc}
\hline Hour details & Amount of Served customer by 4 tellers \\
\hline $08.00-08.59$ & 32 \\
$09.00-09.59$ & 38 \\
$10.00-10.59$ & 41 \\
$11.00-11.59$ & 43 \\
$12.00-12.59$ & 44 \\
$13.00-13.59$ & 41 \\
$14.00-14.59$ & 45 \\
$15.00-16.00$ & 42 \\
\hline Total & 326 \\
\hline Average & $\mathbf{4 0 , 7 4}$ \\
\hline
\end{tabular}

Source: Asia Central Bank (BCA), Metro Indah Mall (MIM) branch office, Bandung, 2016.
From these data, it can be seen that the number of customers who are served mostly is at $12: 00$ to $16: 00$ pm. At peak hours, there are 172 customers served by four tellers within 4 hours, where the average customer can be served for 10.75 minutes. Table 1 also shows that the given service time has not been in accordance with the standard that has been set by the BCA Bank which is 5 minutes per customer per transaction.

In this study, the researchers noticed that there are some phenomena occurring in the queuing system at the service teller BCA Bank, Metro Indah Mall (MIM) branch office. For instance, at the beginning and at the end of the month and also in every Monday and Friday in every week, customers begin to take a queue number since at 7:00 pm and the new service begins at 8:00 pm. In addition, based on observation, there are many customers who take a queue number first and then go away and come back again after a few hours to avoid congested queues, but it affects many empty queue numbers when called. BCA Bank has four tellers employed to serve customers in the process of financial transactions. One factor making the long queue is low-value fractions in each transaction. Another factor is the inexperience of teller officers due to their new employment status. They require adaptation in the process of service.

Thus, the researchers are interested in conducting research on the model queue at BCA Bank located in Metro Indah Mall (MIM) branch office, at Jalan Soekarno Hatta no. 590 Buah Batu, Bandung. The purpose of this study is to determine the exact amount of teller for the BCA teller so the queue matches the standard set, which is 5 minutes.

\section{LITERATURE REVIEW}

The service is any activity or benefit given by one party to another that is essentially intangible and it does not create ownership and production. In the financial institutions, the company should offer financial transactions, customer service, and other financial services. The queue is a common situation in everyday life. According to Jacobs \& Chase (2011), the queue is a sequence of waiting that someone does. Everyone has ever felt the queue, whether it was in a shopping mall, the toll gate, hospitals, banking institutions, 
JURNAL BISNIS \& MANAJEMEN

ISSN 1412 - 3681

and others. In the case of queuing, time is the most important component, therefore the queuing system applied must have adequate facilities and services. So, the consumers do not feel bored when they have to go through the process of the queue.

In the process of the queue, the length of time waiting for the queue becomes an important component because the waiting time has a relationship with the quality of service in a company. The analysis of the queue was first introduced by A.K Erlang in 1913 who studied telephone request fluctuation and delay in service. Currently, the analysis of queue is widely applied in the field of business (such as a teller at the bank), industry (service automated machines), transportation (airports, seaports, services post) and others to measure the average waiting time from the long queue and other factors.

Haryani (2013) stated that queuing theory is an important part of the operation and also a very valuable tool for operation managers. Queues arise due to the demand for services exceeds the ability of service or facilities. Therefore, the users of the facility could not immediately get the service. In many cases, additional care facilities may be given to reduce the queue or to prevent queues. However, the cost driven by additional services will cause a reduction in profits for the company and long queues will result in a loss.

Heizer and Render (2006) argued that the queue is the persons or things in a line waiting to be served and it covers how companies can determine the time and facilities in order to serve customers efficiently. Maarif and Tanjung (2003) stated that the queue is a waiting line of a situation where a number of the physical unions (immigrants) is trying to receive services from limited facilities (providers) so that newcomers have to wait for some time in a row. Based on the above definition it can be concluded that the queue is a waiting row of some consumers who are waiting to be served by the teller.

Sinalungga (2008) stated that queue rule is a rule which was introduced in selecting a customer to be served immediately. The division of the queue rules is (1) First In First Served (FCFS) or First In First Out (FIFO) where the customer who comes first will be served first. For example, the queuing system at the bank tellers and gas stations; (2) Last Come First Served (LCFS) or Last In First Out (LIFO) where the one who comes most recently is served earlier. For example, the queue at the pile of goods in a warehouse, the last incoming goods will be at the top of the pile so it will be taken first; (3) Service in Random Order (SIRO) is a call based on random chance, no matter who arrives first will be served. For example, papers waiting for the lottery winner are determined and taken randomly; (4) Priority Service (PS) is a service priority is given to the customer who has the highest priority even though the lower priority customer had already arrived in the waiting line.

\section{RESEARCH METHODS}

The researchers attempt to show some of the previous studies that have similar points to this study. The objective is to provide originality reinforcement of this research. In the study conducted by Samsir and Mustika (2010) analyzing the teller queuing system at PT. Bank Riau Pekanbaru, the customers coming per day were 273 people in average, while the number of tellers was in average five people per day. It is found that the customers in the queue were 37 people with an average waiting time in the queue of 57 minutes. While the number of tellers provided was 7 tellers. To overcome the problem of the queue, the bank should provide additional teller ready to serve during the busy hours and dates. If the number of the teller is more than 7 people, the queue will be minimized.

Faisal (2005) studied the Queuing Theory Approach: Case from Customer at 8:00 to 11:00 pm at Bank BNI 46 branch Bengkulu. He calculated the customer waiting time, idle time server/teller as well as the optimal number of server/teller. The number of server/ teller needed for optimal customer service for cash deposit and withdraw at Bank BNI 46 is five tellers. The percentage of the unemployed teller is $26.70 \%$ in each teller. However, if Bank BNI 46 decreases the number of the teller to four people, the percentage of the unemployed teller is $8.37 \%$.

The method in this research is a quantitative method. The study is a descriptive research by collecting and compiling data that can provide a clear description of the object under study. The data are then analyzed. The variables in this experiment are: 
Table 2. Operational Variable

\begin{tabular}{|c|c|c|c|}
\hline Variable & Indicator & Dimension & Method \\
\hline \multirow{8}{*}{$\begin{array}{l}\text { Multichannel-Single-Phase } \\
(\mathrm{M} / \mathrm{M} / \mathrm{S}) \text { queue system, } \\
\text { is the method to measure } \\
\text { queue performance with } \\
\text { the indicators. }\end{array}$} & \multirow{8}{*}{$\begin{array}{l}\text { Queue } \\
\text { performance }\end{array}$} & Customer arrival rate & $\lambda=$ the amount of average customer arrival per time seconds. \\
\hline & & Teller service duration & $\begin{array}{l}\mu=\text { the amount of average served customer per time seconds } \\
\text { for each queue line. }\end{array}$ \\
\hline & & Customer arrival rate inside of the queue line & $\begin{array}{l}L_{s}=\text { the amount of average customer who waits for service in } \\
\text { the queue line. }\end{array}$ \\
\hline & & Waiting duration in the queue line & $\begin{array}{l}W_{s}=\text { the amount of average time in the system (both wait time } \\
\text { and perceived service duration }\end{array}$ \\
\hline & & $\begin{array}{l}\text { Amount of customer in queue system (waiting } \\
\text { consideration) }\end{array}$ & $L_{q}=$ the amount of units waited in the queue line. \\
\hline & & Waiting duration of customer in the queue line & $W_{q}=$ spent time in the queue line (waiting consideration) \\
\hline & & Teller rush rate & $\rho=$ system utilization factors \\
\hline & & Amount of Idle teller & $P_{0}=$ idle teller probability in 0 unit in the system \\
\hline
\end{tabular}

This research is conducted at Bank Central Asia branch of Metro Indah Mall (MIM) Bandung. In this study, the data collected are the number of arrival of customers and the number of service facilities (teller). These data are analyzed by using queue formula $\mathrm{M} / \mathrm{M} / \mathrm{S}$ (multi-channel single phase):

First the queue system at BCA Bank uses multichannel queuing system-single-phase $(\mathrm{M} / \mathrm{M} / \mathrm{S})$ where the queuing system $\mathrm{M} / \mathrm{M} / \mathrm{S}$ is in accordance with the problems and objectives of this study. BCA bank has more than one path of service as many as four tellers, while the service system only has one phase (Romadhona, 2014).

Second BCA Bank applies queue discipline of First Come First Serve (FCFS) where the customer who comes first will be served first.

Third BCA Bank has the level of customer arrival following the Poisson distribution since the customer arrival rate could not be ascertained.

Fourth BCA Bank has the pattern of customer arrival time following an exponential distribution because the arrival time between one customer and the other cannot be ascertained in each minute.

Fifth in the system of banking transaction service, BCA Bank has a standard service such as 5 minutes per customer in each teller.

Sixth in the beginning and the end of the month, the number of customers who come to conduct a transaction at BCA teller banking will exceed the queue.

Here the following parameter in $\mathrm{M} / \mathrm{M} / \mathrm{S}$ :

$P_{0}=\frac{1}{\left[\sum_{n=0}^{M-1} \frac{1}{n !}\left(\frac{\lambda}{\mu}\right)^{n}\right]+\frac{1}{M !}\left(\frac{\lambda}{\mu}\right)^{M} \frac{M \mu}{M \mu-\lambda}}$ where $M \mu>\lambda$

$L_{s}=$ the amount of average customer who waits for service in queue line:

$L_{S}=\frac{\lambda \mu\left(\frac{\lambda}{\mu}\right)^{M}}{(M-1) !(M \mu-\lambda)^{2}} P_{0}+\frac{\lambda}{\mu}$

$W_{s}=$ the amount of average time in the system (both wait time and perceived service duration:

$W_{s}=\frac{\lambda \mu\left(\frac{\lambda}{\mu}\right)^{M}}{(\mu-1) !(M \mu-\lambda)^{2}} P_{0}+\frac{1}{\mu}=\frac{L_{s}}{\lambda}$

$L_{q}=$ the amount of customer wait in the queue line:

$L_{q}=L_{s}-\frac{\lambda}{\mu}$

$W_{q}=$ Time spent in the queue line (waiting consideration):

$W_{q}=W_{s}-\frac{1}{\lambda}-\frac{L_{q}}{\lambda}$

The entire calculation of the primary data that has been obtained in this study would be conducted by manual calculation (Kayiyay, 2004). To do this, POM-QM software for Windows Version 4 with modules Waiting Lines was used. After performing the analysis and interpretation to the output results, we determined the optimal number of tellers at each condition so that the company can deliver optimum performance in serving customers well. 
JURNAL BISNIS \& MANAJEMEN

ISSN 1412 - 3681

\section{RESULT AND DISCUSSION}

\section{Customer arrival rate and teller service rate}

The arrival rate is the number of customers coming to receive the services at the teller within a certain time period. Customer arrival rate is Poisson distribution (in assumption). Poisson process (Rasal et al., 2012) is the arrival of another customer which is not dependent on time (unlimited). While the level of BCA Bank teller service is the duration of the services provided by the teller to serve customers that is 5 minutes. The data of customer coming to BCA Bank were obtained from the bank. Based on observation and the results of an interview with the head of BCA Bank, the tellers must be able to serve the customer in 5 minutes for each transaction. But in reality, it needs more than 5 minutes to do that. Here is the arrival data of the customers during the month of January 2016:
If BCA Bank employs 4 tellers, from the data above, here is the following descriptive calculation: $=39$ / day, $=10$ people/hour. Therefore, the result of further measurement is:

First the zero (0) probability of idle teller in the system $\mathrm{PO}=\frac{1}{\left[\sum_{n=0}^{\mathrm{M}-1} \frac{1}{n !}\left(\frac{\lambda}{\mu}\right)^{n}\right]+\frac{1}{M !}\left(\frac{\lambda}{\mu}\right)^{M} \frac{M \mu}{M \mu-\lambda}} /$
$\mathrm{PO}=\frac{1}{\left[\sum_{n=0}^{\mathrm{M}-1} \frac{1}{0 !}\left(\frac{39}{10}\right)^{0}+\frac{1}{1 !}\left(\frac{39}{10}\right)^{1}+\frac{1}{2 !}\left(\frac{39}{10}\right)^{2}+\frac{1}{3 !}\left(\frac{30}{10}\right)^{3}\right]+\frac{1}{4 !}\left(\frac{39}{10}\right)^{4} \frac{4 \times 10}{(4 \times 10)-30}}$ $\mathrm{PO}=0.00232396$, this result concludes that the zero (0) probability of customer availability in the queue system is $0.23 \%$.

Second the amount of average customer who waits for service in the queue line.

Table 3. Customer Arrival Data

\begin{tabular}{|c|c|c|c|c|c|c|c|c|c|c|}
\hline \multirow[b]{2}{*}{ No } & \multirow{2}{*}{$\begin{array}{c}\text { Date } \\
\text { (January } \\
\text { 2016) }\end{array}$} & \multicolumn{8}{|c|}{ Amount of customer in queue line (per hour) } & \multirow{2}{*}{$\begin{array}{c}\text { Amount of } \\
\text { customer } \\
\text { (per day) }\end{array}$} \\
\hline & & $\begin{array}{c}\text { (January } \\
\text { 2016) }\end{array}$ & $09.00-09.59$ & $10.00-10.59$ & $11.59-12.00$ & $12.59-13.00$ & $13.59-14.00$ & $14.59-15.00$ & $15.00-16.00$ & \\
\hline 1 & 4 & 34 & 38 & 43 & 41 & 48 & 55 & 51 & 52 & 362 \\
\hline 2 & 5 & 31 & 33 & 30 & 42 & 47 & 45 & 50 & 50 & 328 \\
\hline 3 & 6 & 30 & 33 & 31 & 35 & 39 & 43 & 36 & 39 & 286 \\
\hline 4 & 7 & 27 & 32 & 30 & 33 & 38 & 36 & 40 & 43 & 279 \\
\hline 5 & 8 & 38 & 44 & 47 & 49 & 50 & 47 & 51 & 49 & 375 \\
\hline 6 & 11 & 33 & 35 & 37 & 39 & 42 & 44 & 46 & 45 & 321 \\
\hline 7 & 12 & 30 & 28 & 34 & 33 & 37 & 36 & 40 & 44 & 282 \\
\hline 8 & 13 & 31 & 34 & 35 & 36 & 40 & 43 & 45 & 46 & 310 \\
\hline 9 & 14 & 30 & 32 & 35 & 36 & 39 & 44 & 46 & 47 & 309 \\
\hline 10 & 15 & 28 & 29 & 31 & 31 & 36 & 39 & 42 & 45 & 281 \\
\hline 11 & 18 & 34 & 32 & 35 & 38 & 37 & 40 & 44 & 44 & 304 \\
\hline 12 & 19 & 26 & 25 & 26 & 29 & 28 & 29 & 31 & 33 & 227 \\
\hline 13 & 20 & 26 & 30 & 29 & 31 & 30 & 31 & 30 & 32 & 239 \\
\hline 14 & 21 & 26 & 27 & 29 & 30 & 32 & 35 & 35 & 36 & 250 \\
\hline 15 & 22 & 30 & 30 & 29 & 32 & 35 & 39 & 40 & 42 & 277 \\
\hline 16 & 25 & 36 & 37 & 40 & 44 & 47 & 50 & 49 & 52 & 355 \\
\hline 17 & 26 & 37 & 38 & 42 & 44 & 49 & 49 & 48 & 52 & 359 \\
\hline 18 & 27 & 38 & 38 & 40 & 43 & 44 & 47 & 49 & 48 & 347 \\
\hline 19 & 28 & 39 & 42 & 41 & 43 & 47 & 48 & 51 & 52 & 363 \\
\hline 20 & 29 & 34 & 36 & 39 & 38 & 41 & 45 & 46 & 47 & 326 \\
\hline & & 638 & 673 & 703 & 747 & 806 & 845 & 870 & 898 & 6180 \\
\hline \multicolumn{10}{|c|}{ The average of service per hour } & 10 \\
\hline \multicolumn{10}{|c|}{ The average of customer arrival rate } & 39 \\
\hline
\end{tabular}


$L_{s}=\frac{\lambda \mu\left(\frac{\lambda}{\mu}\right)^{M}}{(M-1) !(M \mu-\lambda)^{2}} P_{0}+\frac{\lambda}{\mu} / L_{s}=\frac{39 \times 10\left(\frac{39}{10}\right)^{4}}{(4-1) !(4 \times 10-39)^{2}} 0,232+\frac{39}{10}$

$L_{s}=40,759$, the result of the amount of average customer who waits for service in queue line is 41 person.

Third the amount of average time in the system (both wait time and perceived service duration

$W_{s}=\frac{2 s}{\lambda} / W_{s}=\frac{40,759}{39}$

$W_{s}=1.0451$, the result of the amount of average time in the system (both wait time and perceived service duration are 63 minutes.

Fourth the amount of customer waited in the queue line.

$L_{q}=L_{s}-\frac{\lambda}{\mu} / L_{q}=40,759-\frac{39}{10}$

$L_{q}=36.8595$ persons, the result of the amount of units waited in the queue line is 37 persons.

Fifth time spent in the queue line (waiting consideration)

$W_{q}=\frac{L_{q}}{\lambda} / W_{q}=\frac{36,8595}{39}$

$W_{q}=0.9451$ hour, the result of time spent in the queue line (waiting consideration) is $\mathbf{5 7}$ minutes.

From the calculation result above, it can be seen that problem in the system queue in BCA Bank MIM branch office is the length of time spent by a customer in the queue (in the system or Ws), which is 63 minutes.
Bank in order to find the right number of tellers in accordance with Standard of BCA Bank.

Based on the calculation above, the average arrival rate per hour was 309 persons while the number of tellers was 4 people per day. From the real labor skill, it can be analyzed that the ability to serve customers for each teller is 10 persons every hour, the average arrival rate of customers is 39 people per hour, the probability of zero (0) customer in the system is $0.23 \%$, the level of teller activity is $97 \%$, the average number of customers in the system are 41 people. However, the average number of customers waiting in the queue are 37 people, the average time for a customer to wait in the queue is 57 minutes and the calculation of the average time a customer in the system is over 63 minutes. This duration is the status quo in the field at the BCA Bank where the waiting time of customers in the system is not in accordance with the SOP of BCA Bank in MIM Bandung.

We tried to evaluate the queuing system at Bank Central Asia (BCA) by adding the number of tellers to $5,7,8$, and 15 tellers per day. The result of increasing the number of tellers is obtained from the calculation of POM-QM for Windows Version 4 by adding the number of tellers to reach the time (Ws) approaching (Berhan, 2015) or in accordance with Standard in Bank Central Asia (BCA) Branch Metro Indah Mall (MIM) Bandung and we change (U) calculations based on the number of tellers available.

The table above illustrates that the differences are significant if the number of teller operations improved as revealed by Goldstein (2009). If the tellers are 5

Tabel 4. Comparison between waiting time spent in the queue

\begin{tabular}{|c|c|c|c|c|}
\hline Description & $\lambda: 39, \mu: 8, \mathbf{M}: 5$ & $\lambda: 39, \mu: 6, \mathrm{M}: 7$ & $\lambda: 39, \mu: 5, \mathrm{M}: 8$ & $\lambda: 39, \mu: 3, \mathrm{M}: 15$ \\
\hline (p) & 0,975 & 0,928 & 0,975 & 0,866 \\
\hline$(\mathrm{Lq})$ & 37 person & 10 person & 36 person & 3 person \\
\hline (Ls) & 41 person & 17 person & 44 person & 16 person \\
\hline$(W q)$ & 56 Minutes & 16 Minutes & 55 Minutes & 5 Minutes \\
\hline (Ws) & 64 Minutes & 26 Minutes & 68 Minutes & 25 Minutes \\
\hline Service duration & $64-57=7$ minutes & $26-16$ = 10 Minutes & $68-56=12$ Minutes & $25-5=20$ Minutes \\
\hline $\begin{array}{l}\text { The amount of servicing } \\
\text { customer }\end{array}$ & $42-37=5$ person & $17-10=7$ person & $44-36=8$ person & $16-3=13$ person \\
\hline
\end{tabular}

Source: Calculated result of POM-QM, 2016

This is not in accordance with Standard of 5 minutes. Thus we tried to evaluate the queuing system at BCA people per day, there will be 37 people waiting in the queue, 41 people in the total system, and each 


\section{JURNAL BISNIS \& MANAJEMEN}

ISSN 1412 - 3681

customer will spend 56 minutes waiting in the queue and 64 minutes in the total system. But if the tellers are 7 per day, the number of customers waiting in the queue is 10 people and in the total system are 17 people. In addition to the time they spend in the queue of16 minutes, the time to wait in the total system is 26 minutes.

However, if the number of the teller is increased to 8 tellers per day, there will be less significant change. With this number, there will be 36 people waiting in the queue, 44 people waiting in the total system, and the customers will spend 56 minutes to wait in the queue and 68 minutes in the total system. However, if the number of the teller is increased to 15 people per day, there will be a very significant change in Lq, Ls, and Wq. With this number, there will be three people waiting in the queue, 16 people waiting in the total system and customers will only spend 5 minutes to wait in a queue. But customers will spend 25 minutes to wait in the total system.

Table 4 also describes the increasing number of teller operation, the increasing number of customers who could be served, and every customer has longer opportunity to be served. In other words, the customers can be served as they expected without haste but the customers will still wait more than 5 minutes in the system. Based on the calculation, the optimum teller at Bank Central Asia (BCA) Bank is 7 tellers. As currently there are only four tellers, to achieve the optimal result, BCA needs to add 3 more tellers per day. The benefits of adding the teller to seven people are: (1) The average number of customers waiting in the queue will reduce to 10 persons, (2) the average number of customers in the system will reduce to 17 people, (3) the average time it takes by a customer to wait in the queue will reduce to 16 minutes and (4) the average time needed by each customer to wait in the system will reduce to 26 minutes. This number can be said to be optimal because the waiting time in the system is reduced significantly from 63 minutes to 26 minutes.

\section{CONCLUSION}

Based on the analysis performed, it is shown that the number of tellers is 4 people per day and the average number of customers coming per hour are 39 people. So, a teller must be able to serve 10 customers per hour. In this state, there are about 37 people waiting in the queue and 41 people waiting in the total system. The average time for a customer to wait in the queue is $\mathbf{5 7}$ minutes and the time for a customer to wait in the system is 63 minutes. Based on the calculation, the optimal number of teller in this financial institution is seven tellers. Therefore, considering the current situation, BCA is required to add three more tellers per day.

As the suggestion, firstly, BCA Bank in MIM branch office should increase the number of tellers to 7 people per day. It will positively impact the customer queue at BCA Bank transaction system as it will reduce the waiting time significantly. Secondly, if the number of tellers is 7 people per day, the average time for a customer to wait in the system is 26 minutes. This time can be submitted to Bank BCA as there is no SOP in the system. Thirdly, if the number of tellers is 7 people per day, the average time for a customer to wait in the queue is 16 minutes. This time can be submitted to Bank BCA as the SOP has not been adjusted and determined in the current circumstance. Finally, the researchers suggest the further research to study the queue cost and layout.

\section{Acknowledgment}

This research conducted by lecturer team of Business Administration and supported by Research Centre of Telkom University. Authors would like to thank all the staff of BCA Bank Branch Metro Indah Mall (MIM) Bandung, managers. Author also thanks to colleagues, students and all partners who spare their valuable time to support this research, throughout direct and indirect support

\section{REFERENCES}

Arikunto, S. (2006). Prosedur Penelitian Suatu Pendekatan Praktik. Jakarta: Rineka Cipta. Bank Central Asia. (2014). About BCA. [Data file]. Retrieved from http://www.bca.co.id/ id/about/caritahu-tentang-bca/visi-misi/ visimisi_landing.jsp

Berhan, E. (2015). Bank Service Performance Improvements using Multi-Sever Queue System. IOSR Journal of Business and 
Management (IOSR-JBM), 17, Issue 6.Ver. I.

Faisal, F. (2005). Pendekatan Teori Antrian: Kasus Nasabah Bank pada Pukul 08-00-11.00 WIB di Bank BNI 46 Cabang Bengkulu. Jurnal Gradien, 1(2).

Goldstein D. S., (2009). Improved Customer Satisfaction Through Dedicated Service Channel. Journal of Applied Business and Economics, 5, 1-34.

Haryani, R. (2013). Analisis Penerapan Teori Antrian Pada Sistem Pembayaran Supermarket Di Golden Market Jember. Fakultas Ekonomi Universitas Jember.

Heizer, J., \& Render, B. (2006). Operation Management (Manajemen Operasi). (7th ed.). Jakarta: Salemba Empat.

Ivancevich, J. M., Lorenzi, P., Skinner, S., \& Crosby, Philip B. (1997) Manajemen Quality and Competitiveness. Chicago: Irwin.

Jacobs, R., \& Chase, R. (2011). Operation and Supply Chain Management. (14th ed.) New York: McGraw-Hill Education.
Kayiyay, T. J. (2004). Dasar Teori Antrian Untuk Kehidupan Nyata. Yogyakarta: Andi.

Maarif, M.S \& Tanjung. (2003). Manajemen Operasi. Grasindo. Jakarta.

Samsir \& Mustika, R. (2010). Analisis Sistem Antrian Teller Pada PT. Bank Riau Cabang Utama Pekanbaru. Jurnal UNRI, 18, 02.

Sinalungga, S. (2008) Pengantar Teknik Industri, Graha Ilmu: Yogyakarta.

Sunarya, R., Aritonang, M., Helmi. (2015). Analisis Penerapan Sistem Antrian Model $\mathrm{M} / \mathrm{M} / \mathrm{S}$ Pada PT. Bank Negara Indonesia (Persero) Tbk. Kantor Cabang Pontianak (Studi Kasus pada BNI Sultan Abdurrahman). Bimaster, 04 (02).

Rasal, I., Wahyud, H., Mukarromah, N., Hanum, Y. (2012). Simulasi dan Optimasi Antrian Pelayanan Agen JNE Buaran. KOMMIT, 2012 (7).

Romadhona, R. (2014). Kalkulasi dan Analisa Model Antrian M/M/1/I/I Pada Bagian Teller Service Bank Syariah Mandiri Bogor. Jurnal Teknik Industri, Vol 19, (3). 